\title{
EL NIÑO AND THE BIRDS: A RESOURCE-BASED INTERPRETATION OF CLIMATIC FORCING IN THE SOUTHEASTERN PACIFIC
}

\author{
EL NIÑO Y LAS AVES: UNA INTERPRETACIÓN BASADA EN EL USO DE RECURSOS \\ FRENTE AL FORZAMIENTO CLIMÁTICO EN EL PACÍFICO SUDORIENTAL
}

Fabián M. Jaksic ${ }^{1} \&$ José M. Fariña ${ }^{1,2}$

\begin{abstract}
Through a review, we attempt to identify what aspects of El Niño-Southern Oscillation (ENSO) determine the availability of resources that affect avian ecology in the southeastern Pacific. We recognized three functional bird types: seabirds, waterbirds, and landbirds (the latter separately treated as granivorous, insectivorous, carnivorous). The evidence shows that El Niño affects seabirds by reducing their food base. Seabirds feeding on fish, or fish plus squid, generally decrease their population abundance, as a combined result of adult mortality and reproductive failure. Omnivorous seabirds negotiate El Niño periods with modest declines, while those including fishery wastes in their diets show minimal changes during such periods. Waterbirds in the southeastern Pacific benefit from precipitation that accompanies El Niño, which enlarges their wetland habitats. Finally, landbirds are favored by El Niño-driven precipitation, which fires up primary productivity fuelling arthropod and mammal increases. Granivorous birds react promptly to peaks in seed output, while insectivores respond similarly to arthropod abundance. Carnivorous birds take somewhat longer to react to increases in mammal populations. We conclude that (a) Food shortage may be an important key factor for bird populations in the southeastern Pacific, but its effects depend on diet breadth, prey switching, and life history parameters. (b) Seasonal patterns of productivity determine distribution and abundance of resident birds, but variations imposed by occurrences of El Niño and La Niña phases determine the presence and abundance of migratory birds. (c) The dichotomy El Niño versus La Niña or versus 'normal' years is artificial and non conducive. (d) Long-term monitoring is needed to understand the connection between climate and birds.
\end{abstract}

Key words: seabirds, waterbirds, landbirds, food shortage, seasonal patterns, dichotomy El Niño/ La Niña, long-term monitoring.

\section{RESUMEN}

Mediante una revisión exhaustiva, tratamos de identificar qué aspectos del fenómeno El Niño-Oscilación Sur (ENOS) determinan la disponibilidad de recursos que afectan a la ecología aviar en el sudeste del Océano Pacífico. Hemos distinguido tres tipos funcionales de aves: marinas, acuáticas y terrestres (este último grupo subdividido en granívoros, insectívoros y carnívoros). La evidencia muestra que El Niño

${ }^{1}$ Center for Advanced Studies in Ecology \& Biodiversity, Pontificia Universidad Católica de Chile, P.O. Box 114-D, Santiago, Chile, ${ }^{2}$ Department of Ecology and Evolutionary Biology, Brown University, Providence, RI 02912, USA. Corresponding author F.M. Jaksic: Phone: +56-2-354 2620. Fax: +56-2-354 2621, fjaksic@bio.puc.cl 
afecta a las aves marinas mediante la reducción de su sustento alimenticio. Las aves marinas que se alimentan exclusivamente de peces, o peces sumados a calamares, por lo general disminuyen su abundancia poblacional, como resultado combinado de la mortalidad de adultos y del fracaso reproductivo. Las aves marinas omnívoras franquean los períodos de El Niño con descensos poblacionales moderados, mientras que aquellas aves que incluyen en su dieta residuos de la industria pesquera muestran cambios mínimos. Las aves acuáticas en el sudeste del Pacífico se benefician de la precipitación que acompaña a El Niño, al ver ampliados sus hábitats de humedales. Por último, las aves terrestres se ven favorecidas por el incremento en la precipitación asociado al fenómeno El Niño, que conlleva un incremento de la productividad primaria y por consiguiente de la abundancia de artrópodos y mamíferos. Las aves granívoras reaccionan con rapidez a los máximos de la producción de semilla, mientras que las aves insectívoras responden de manera similar a la abundancia de artrópodos. Las aves carnivoras tardan un poco más en responder a los aumentos en las poblaciones de mamíferos. Concluimos que: (a) La escasez de alimento es un factor clave para las poblaciones de aves en el sudeste del Pacífico, pero sus efectos dependen de la amplitud de la dieta, la alternancia de presas, y los parámetros de historia de vida. (b) Los patrones estacionales de productividad determinan la distribución y abundancia de aves residentes, pero las variaciones impuestas por las fases alternas El Niño y La Niña determinan la presencia y abundancia de aves migratorias. (c) La dicotomía El Niño versus La Niña o versus "años normales" es artificial e inconducente. (D) El seguimiento a largo plazo es necesario para entender la conexión entre el clima y las aves.

Palabras clave: aves marinas, aves acuáticas, aves terrestres, escasez de alimentos, patrones estacionales, dicotomía El Niño/La Niña, seguimiento a largo plazo.

\section{INTRODUCTION}

There is plenty of anecdotal information that $\mathrm{El}$ Niño affects different aspects of avian ecology, ranging from individual to population to community aspects. Most of the evidence is qualitative and correlational at most, with few attempts to relate emerging patterns to underlying causes (see reviews by England 2000, Jaksic 2001, 2004). Pioneer exceptions were the publications by Jordan (1964) ${ }^{1}$ and Tovar (1983, 1987) on guano birds in Peru, Boersma (1978) on Galapagos penguins in Ecuador, Harris (1979) on flightless cormorants in Ecuador, Graybill \& Hodder (1985) on seabirds in Oregon USA, and Hays (1986) on Humboldt penguins in Peru. A benchmark was the publication of the proceedings of the 'Symposium on birds and the El Niño Southern Oscillation' (convened by R. W. Schreiber and D. C. Duffy in 1986), which concentrated on El Niño 1982-83 and examined its effects on Peruvian, Caribbean and Atlantic seabirds (Duffy et al. 1988), on North and South Pacific seabirds (Ainley et al. 1988), and on landbirds of North and South America (Hall et al. 1988). Foresightedly, Schreiber \& Schreiber (1988) prefaced that such symposium was meant, among other things "...to encourage ornithologists to carry out long-term studies that will shed further light on the interactions between global atmospheric cycles, oceanographic phenomena, and avian populations."

But not much heed was paid to that recommendation. Most of the blame may be placed on the fact that the following El Niño's were much weaker (and less spectacular) than that of 198283. Indeed, those of 1986-87 and 1991-92 failed to elicit interest from ornithologists (see Anderson 1989, Lindsey et al.1997, for exceptions). Only with the advent of the strong El Niño of 1997-98 was there a renewed thrust on trying to understand this phenomenon with regard to birds in general (England 2000, Jaksic 2001, 2004). These latter three studies suffered some shortcomings: the first because it did not show any data, the second because it was broadly scoped, briefly touching on birds, and the third because it showed preliminary data delivered as a plenary lecture at a meeting. Thus, it seems timely to address this issue again, with emphasis on quantitative data.

Here, we attempt to remedy the lack of synthesis on the putative effects of El Niño on birds, through a review of accumulated evidence. We attempt to determine which aspects of El Niño (an oceanographic/atmospheric phenomenon) determine the availability of resources (food and habitat) 
that in turn affect avian ecology in the southeastern Pacific. We found that El Niño has contrasting effects, some positive and some negative, depending on the types of birds considered, and on the types of responses measured.

\section{MATERIAL AND METHODS}

We concentrated our literature search on the southeastern fringe of the Pacific Basin (including the Galapagos Archipelago), an area with which we are familiar and where most of the known effects of El Niño on birds have been reported. Nevertheless, we also considered results from the equatorial Pacific (Kiritimati Island, also known as Christmas Island but not located in the Indian Ocean) and northeastern Pacific (French Frigate Shoals, 500 km northwest of Hawaii), where seabirds have been particularly well studied. We searched the primary literature for quantitative, or at least categorical, data on bird abundance (and migration), mortality (or survival) and reproduction (or lack thereof), in connection with fluctuations in prey and habitat resources. We recognized three functional bird types: seabirds, waterbirds, and landbirds, regardless of systematic affinities.

With respect to seabirds, when enough references were available (e.g., Ashmole \& Ashmole 1967, Castro \& Phillips 1996, Duffy 1983b), we characterized their main prey for four regions: $\mathrm{Ki}-$ ritimati Island, French Frigate Shoals, Galapagos Archipelago, and Peru. Following the methods of Shealer (2002), a Jaccard presence/absence coefficient of similarity (Jaccard 1901, Sneath 1957) was used to analyze similarity in diet composition of the seabirds living in each region. The pattern of similarity was contrasted using a cluster diagram of the Jaccard coefficients calculated for each species. The cluster was constructed using un-weighted average linkage methods (Wilkinson et al. 1996) and the significant level of similarity was estimated using the distribution of the Jaccard coefficients, calculated after bootstrapping 1000 times the prey matrix (Clarke 1993). To test the hypothesis that $\mathrm{El}$ Niño effects depend on diet preferences of seabirds, for each region we summarized reported changes in abundance and reproduction of the species belonging to every dietary group. For each group (cluster) we proceeded as follows: for any change in abundance, the reported percentage was registered using negative values for decreases (due to increased mortality or emigration) and positive value for increases (usually associated with immigration). Similarly, any decrease in reproduction (nesting, clutch size, brood size, chick size, or survival) was denoted by its reported percentage in negative values and any increase by positive values. For our analysis we considered a threshold of $5 \%$ for a detected change. That way, in cases when changes on abundance or reproduction were mentioned but no percentage was given, we assumed a minimum effect of $\pm 5 \%$. In cases when no change was mentioned we assumed $0 \%$. We then averaged all the effects reported for each species, calculating the twice-standard error for each dietary group (data in tables 1 and 2).

Seabird species are referred to by common names throughout the text, but their scientific names may be found in table 1 .

For waterbirds, all information that was available was so limited, that there was no need to use screening procedures, and therefore we analyzed all that was available. In this case, all usable data came from Chile.

For landbirds, we further divided this category among granivorous, insectivorous and carnivorous birds, because there were enough data to address these avian consumers separately. Most of the usable data came from the Galapagos Archipelago, Chile, and Argentina.

\section{RESULTS \\ Seabirds}

In the Pacific region, occurrences of El NiñoSouthern Oscillation (ENSO) are associated with dramatic changes in seabird geographic distribution, population abundance, survival, and reproductive success (Arntz \& Fahrbach 1996). Although a direct link between oceanographic events and seabird breeding failures and die-offs has been observed since long ago (Murphy 1926, 1936, Vogt 1942²), there is no clear determination of the mechanisms responsible. One of the most severe $\mathrm{El}$ Niño events occurred during 1982-83, and several studies gathered information about the changes on southeastern Pacific Ocean seabird populations. Below we document those responses.

\footnotetext{
${ }^{2}$ Vogt, W. 1942. Aves guaneras. Boletín de la Compañía Administradora de Guano del Perú. 18, 127-167.
} 
Effects on migration, abundance and distribution

Murphy $(1925,1926)$ first noted massive migrations of resident seabirds away from Peruvian waters during El Niño events. Ainley et al. (1988) reported that in association with the 1982-83 El Niño, in February 1983, over 7,000 Peruvian Boobies and 10,000 Blue-footed Boobies appeared suddenly at the Bay of Panama. The occurrence of atretic follicles in Peruvian Boobies suggested that their reproductive cycles had been cut off sharply just prior to laying. The two species began to lose weight when fish disappeared in May. By August 1983, many Peruvian Boobies had died and Blue-footed Booby populations decreased by $50 \%$. On June 1984 , no Peruvian Boobies and only 75 Blue-footed Boobies remained in the Bay of Panama (Ainley et al.1988).

Distributions of seabirds are known to shift with movements of their preferred water temperatures (Ainley 1976, Spear et al. 2001). The 1982-83 El Niño confirmed this phenomenon. Duffy \& Merlen (1986) compared bird counts in the Galapagos Archipelago during and after El Niño and reported species-specific changes in occurrence. Some species left (Audubon's Shearwater, Wedge-rumped Stormpetrel, Red-billed Tropicbird, Blue-footed Booby, Frigatebirds, Northern Phalarope, Swallow-tailed Gull, Brown Noddy and Galapagos Penguin), some arrived (Dark-rumped Petrel, Oceanites sp. Storm-petrel), while others remained in the Archipelago (Waved Albatross, White-vented Storm-petrel, Band-rumped Storm-petrel, Brown Pelican, Masked Booby and gulls). In central and northern California, Briggs et al. (1983) and Massey et al. (1992) reported that at the beginning of autumn 1982, cool-water species were noticeably less abundant, and warm-water species more abundant, than expected. By mid- to late 1983, even greater adjustments in California marine avifaunas occurred, when species normally not present in the northern part began to appear (Ainley et al.1988). Later, warm-water species such as Black-vented Shearwater, Black Storm-Petrel, Craveri's Murrelet and Brown Booby appeared at Farallon Islands and in some cases remained through the winter of 1984-85. These occurrences were preceded by the unusually early arrival and late departure of large numbers of Brown Pelicans and Heermann's Gulls. The same happened during the El Niño 1972-73 (Anderson \& Anderson 1976). In the central subarctic Pacific, Wahl et al. (1989) re- ported higher than expected numbers of cool-water species in 1983, as if individuals had spread out, rather than concentrated in the more productive eastern margin as they usually do.

\section{Effects on mortality and reproduction}

Mortality of Peruvian guano birds as a result of El Niño is well known (Murphy 1925, 1936, Vogt $1942^{2}$, Jordan \& Fuentes 1966³, Duffy 1983a, Ainley et al. 1988). During the 1982-83 El Niño, large numbers of dead and dying birds were observed at several places throughout the eastern Pacific (Ainley et al. 1988): boobies and Brown Pelicans in the Galapagos Archipelago and in Panama; cormorants, Common Murres and Pigeon Guillemots in California; murres and guillemots in Oregon; Short-tailed Shearwaters and Black-legged Kittiwakes in Alaska and the Bering Sea.

The absence of, or the decrease in, adults attempting to nest during 1983 meant a lower reproductive output for eastern Pacific seabirds. Schreiber \& Schreiber (1984) reported low nesting success of most Sooty Terns at Kiritimati Island in 1983, although the few individuals of other species that attempted to breed were generally successful. At French Frigate Shoals, only $51 \%$ of Black Noddy pairs successfully fledged young, compared with $65 \%$ in 1981 , and $69 \%$ in 1984 . The asymptotic weight of Black Noddy chicks in 1982 and 1983 was only $108 \pm 2 \mathrm{~g}$ (mean \pm standard deviation), compared with $112 \pm 2 \mathrm{~g}$ in 1980 and $115 \pm 2 \mathrm{~g}$ in 1981 . Asymptotic weights of Red-footed Booby chicks were also lower in $1982(1178 \pm 50 \mathrm{~g})$ and 1983 $(1165 \pm 20 \mathrm{~g})$ as compared with 1980 (1207 \pm 20 g) and 1981 (1222 \pm 20 g). Similarly, the weight of Dark-rumped Petrel chicks in the Galapagos Archipelago showed an effect of El Niño: At age 45 days they weighed $290 \pm 69 \mathrm{~g}$ in 1983 compared with the 1981, 1984 and 1985 mean of $415 \pm 52 \mathrm{~g}$ (Ainley et al. 1988). By the time chicks fledged, the between-year weight disparity had disappeared. The shape of the growth curve was unusual in 1983: it lacked the pre-fledging maximum typical of petrels. Chicks required longer fledging in 1983 (119 \pm 6 days) than in other years (108 \pm 6 to $113 \pm 5$ days).

It seems reasonable to relate the reproductive failure and high mortality that occurred at some localities with the arrival of El Niño 1982-83. Some nesting populations such as Flightless Cormorant 
in the Galapagos Archipelago, Graybacked Tern at French Frigate Shoals, Masked Booby at Jarvis Islands, Red-tailed Tropicbird at Kiritimati Island, and Brown Pelican in the Gulf of California, almost disappeared during 1983 and returned only after 1984. In some cases, the apparent stability of population sizes could be an artifact of recruitment from 'floating' populations. This was evident from a dramatic turnover among banded, breeding individuals, and the much lower numbers of non-breeding adult and sub-adult birds observed among Western Gull and Cassin's Auklet at the Farallon Islands (Ainley et al. 1988; see also Schreiber 1994 for Red-tailed Tropicbirds, and Ludwig et al. 2000 for Black-footed Albatross).

Effects on food web structure and rainfall regime By comparing the effects of El Niño 1982-83 on seabirds of Peru and the Atlantic Ocean, Duffy et al. (1988) developed the idea that migration and mortality (or survival) of seabird populations could be associated with alterations of the marine food web, while changes in reproduction could be related with alterations of atmospheric circulation and with increased rainfall. These authors proposed that changes in the marine food web, mainly associated with a replacement of primary producers -from dinoflagellates to diatoms-, and of primary consumers -from copepods to chaetognaths- (Arntz \& Fahrbach 1996) produced the migration to deeper water of the main secondary consumers -anchovies and sardines-, the preferred prey of seabirds. Hence, the massive migrations and die-offs of Peruvian seabirds was especially evident among surface feeders, including divers, pursuit plungers, and deep plungers, which require fairly reliable food sources (Shealer 2002), including Peruvian Boobies, Peruvian Pelicans, and Guanay Cormorants. Other birds turned to unusual food sources: Brown Pelicans and Inca Terns went to fishing terminals and ports; Guanay Cormorants, flock feeders specializing on pelagic fish species, fed inshore on mullet Mugil sp. (Arntz 1985), or died while attacking fish in nets (Herdson 1984). Arntz \& Fahrbach (1996) reported that the main cause of changes observed during El Niño 198283 on seabird populations of Kiritimati Island and Galapagos Archipelago was shortage of food due to migration of pelagic prey (mostly fishes and squid) toward deeper water. But concurrent changes such as a higher plant cover due to increased rainfall, and flooding of seabird reproductive grounds due to increased sea level, were also important causes of reproductive failures.

For Kiritimati Island, Schreiber \& Schreiber (1984) determined the breeding chronology and reproductive attempts of the local seabird assemblage during 1982-83. Most seabirds on these islands have the following breeding characteristics: one large egg, long incubation period, extended parental care, post-fledging feeding of juveniles, deferred maturity, and long life span. These features are assumed to indicate pelagic food habits based on distant and ephemeral food supplies of small fish and squid. These pelagic birds depend on predatory fishes and marine mammals to drive smaller fishes and squid up toward the ocean surface. Therefore, these seabirds are thought to be limited by food availability. Data from Kiritimati Island collected from the 1940s to June 1982 revealed no reproductive failure of any species during that long period, when fishes and squid were the primary food source. But in November 1982, there was a total reproductive failure of all species present and a virtual disappearance of all individuals from the islands (Schreiber \& Schreiber 1984). This situation was maintained until the end of 1983 . Of 18 seabird species, 16 showed severe reductions of their population sizes while two (Crested Tern and Black Noddy) remained at their normal numbers. All the species but Crested Terns showed reproductive failures. Several of these failures were associated with increased rainfall. For example, despite populations being reduced by only 1 or $2 \%$ of normal levels, Great Frigatebirds nested, but all nests were either empty or were destroyed by rain. Black Noddy remained at normal population sizes but all nests were washed out of trees by rain. Schreiber \& Schreiber (1984) concluded that in addition to the reduction of the already low primary productivity levels, the high sea level accompanying the heavy rains caused extensive flooding, and adult birds were either flooded out of nests or their breeding activity was inhibited by rain.

For the Galapagos Archipelago, Valle et al. (1987) presented a detailed report on seabird population responses to El Niño 1982-83. These authors showed that the El Niño event began when higher than normal sea surface temperatures and heavy rains were recorded. Observations of seabird breeding colonies indicated low or no reproductive 
effort from July to September 1983. Ten species temporarily interrupted their breeding cycles, deserting young or eggs or not even attempting to breed: Galapagos Penguin, Flightless Cormorant, Waved Albatross, Audubon's Shearwater, Wedged-rumped Storm Petrel, Brown Pelican, Blue-footed Booby, Masked Booby, Red-footed Booby and Swallowtailed Gull. Five other species bred during their normal period, but reproductive success was low: Dark-rumped Petrel, Red-billed Tropicbird, Great Frigatebird, Magnificent Frigatebird, and Lava Gull. Of 15 seabird species, 10 gave up breeding, while 5 continued breeding with low reproductive success. In general, seabirds feeding closer to shore (Galapagos Penguin, Audubon's Shearwater, Brown Pelican, Blue-footed Booby and Flightless Cormorant) were the most affected. This was particularly apparent in those species normally feeding in cold, upwelled waters (penguin and cormorant). These waters were displaced during El Niño 1982-83. Valle et al. (1987) and Cruz \& Cruz (1990) pointed out that the slower growth rate and the death of large chicks observed in some species (Dark-rumped Petrel and Great Frigatebird), which did not abstain from breeding, could be associated with a severe decrease in food abundance, but also with rainfall collapsing burrows of the ground-nesting Dark-rumped petrel, and with increased plant cover on Frigatebird nesting places, which made the movements of this species more difficult. These effects were most evident in the case of Waved Albatross nesting on Española Island, where all nesting grounds were flooded and covered by plants. It is worth mentioning that the only successful breeders were species with scavenging habits. Those species with population decreases, as well as with low or no reproduction, comprised inshore and pelagic foragers apparently unable to shift to alternative foods.

\section{Effects of fisheries}

The largest decreases of seabird populations along Peruvian and Chilean coasts since 1909 have been associated with El Niño events (Arntz \& Fahrbach 1991). Due to their dependence on anchovies, which usually disappear during El Niño, Peruvian Booby, Guanay Cormorant and Peruvian Pelican are highly sensitive to the occurrence of El Niño, but also to anthropogenic activities such as guano exploitation and fisheries. For instance, by the end of the 1950s, and partly due to artificially increased nesting facilities (Jordan \& Fuentes 1966) ${ }^{3}$ these three seabird species increased their abundances almost five times, reaching a total of 20 million individuals.

Fisheries became important in the early 1960s, when anchovies (Engraulis ringens) began to be processed into fishmeal. The industry grew spectacularly, from less than 1 million metric tones in 1955 to 12.3 million metric tones in 1970 . Overfishing and the El Niño 1972-73 led to a dramatic reduction in catches, to the point that the record catch has never again been approached. Instead, the fishery switched to sardines (Sardinops sagax) in Peru and to the Peruvian horse mackerel (Trachurus murphyi) in Chile. El Niño events have always had a negative influence on guano bird populations, but severe crashes have only been apparent since fishing activities intensified (Duffy et al. 1984). A possible explanation is that the anchovy fishery took up the superabundance of food on which the seabirds depended to cope with the crashes induced by oceanographic perturbation (Duffy 1983a, Arntz \& Fahrbach 1991, Crawford \& Jahncke 1999). Another explanation is that anchovies and sardines alternate in abundance over decadal scales and that anchovies are able to sustain higher seabird populations than do sardines or mackerels (Chávez et al. 2003).

\section{Mechanisms invoked}

El Niño 1982-83 affected species living in four areas of the South Pacific in different ways. On Kiritimati Island, Schreiber \& Schreiber (1984) reported that 16 of 18 seabird species suffered nesting failures ranging from $70 \%$ to $100 \%$. Black Noddy populations showed a reduction of $100 \%$ in chick survival, while Crested Tern did not show changes in either reproduction or survival. With regard to mechanisms involved, Schreiber \& Schreiber (1984) mentioned that reproductive failures of the Great Frigatebird and the Black Noddy were due to the effect of rain, which flooded or destroyed their nests. But no mechanistic explanation was offered for the failures of other species.

At French Frigate Shoals, Ainley et al. (1988) reported a reduction of $10 \%$ in the reproductive output of two species: Black Noddy and Red-footed Booby. In this case, no mention was made of any causal mechanism for these effects.

In the Galapagos Archipelago, 22 seabird 
species were studied during the 1982-83 El Niño. Eleven of the species showed a decrease in nesting success; three species had reduced chick size and survival, and nine species showed decreased abundances -due to mortality or migration-. On the other hand, seven species showed no significant changes in abundance or reproduction, while two species (Dark-rumped Petrel and an Oceanites sp. Storm Petrel) increased their abundances. The Darkrumped Petrel also showed higher nesting densities, but with chicks of smaller size. In terms of mechanisms invoked, food shortage was associated with the reduction in size of Dark-rumped Petrel chicks as well as with the reduction of Great Frigatebird chick survival. Due to the unusual amount of rainfall, coastal vegetation increased considerably. This phenomenon was associated with the increase in Dark-rumped Petrel nesting and with the reduction in nesting success of Waved Albatross and Bluefooted Booby. Despite the high number of species affected, no other mechanisms were mentioned to explain the observed effects.

In the Peruvian coast, eight of 11 species showed decreased abundances (ranging from $50 \%$ to $100 \%)$ due to massive die-off and migration. Three species displayed no changes in abundance, but Cormorants, Inca Terns and Brown Pelicans shifted diets. For all cases food shortage was mentioned as the main cause.

\section{Trophic ecological effects}

Diet studies on breeding seabirds abound so that more is known about what seabirds eat than any other aspect of their ecology. The prey type that seabirds select can have important fitness consequences, particularly during the chick-rearing period (Pierotti \& Annett 1990). Diets of breeding seabirds usually consist of a very limited range of taxa: primarily pelagic fishes, squid and crustaceans (krill and euphausiids) (Montevecchi \& Myers 1996). Nevertheless, the composition of such diets is not static between years, seasons, or even weeks. Changes in diet more likely reflect changes in the marine prey base, or shifts in foraging habitat, than they reflect inherent changes in seabird preference (Ainley \& Boekelheide 1990, Ainley et al. 1993, 1995, Montevecchi et al. 1995, 1996, Ainley \& Divoky 2001, Spear et al. 2007, Ainley \& Tukenian 2010). Thus, diet studies are used as indicators of the health of the marine ecosystem, because prey harvest often is correlated with prey abundance at a variety of scales (Montevecchi \& Myers 1995), and changes in seabird diet often reflect variations in the prey base (Montevecchi et al. 1998, Crawford \& Jahncke 1999, Jahncke \& Goya 2000). Baird (1990) suggests that surface feeders are more vulnerable than subsurface feeders to environmental changes, but this is opposite to much of the evidence (Duffy 1983b, D.C. Duffy pers. comm. 2005, Ainley \& Tukenian 2010).

In terms of its exploitation, the ocean represents a challenge for seabirds. The problem of finding enough food to survive and reproduce in this realm has generally been solved in one of three ways. Coastal or inshore species, such as most gulls and terns, gather to feed in areas where prey are abundant or where they are forced to the surface. Diving seabirds, including penguins and alcids, can exploit a greater range of depths to obtain food. Pelagic species, such as albatrosses, shearwaters, and some petrels, soar over vast expanses of the ocean surface at a relatively low energy cost in search of widely dispersed surface prey. Seabirds may feed either during daylight hours (diurnally) or at night (nocturnally). Presumably these diel habits are a response to the behaviour of their primary prey. Nevertheless, some species such as Red-footed Boobies and Red-tailed Tropicbirds may forage during both day and night (Schreiber \& Schreiber 1993).

During periods of reduced food availability, such as El Niño years, seabirds may be forced to switch their diet from foods that enable them to survive and reproduce (Pierotti \& Annett 1990, Jahncke \& Goya 2000). During these periods seabirds can maximize the chances of their own survival by not breeding rather than by attempting to breed and risk death of both adult and offspring (Goodman 1974, Harris et al. 1998). Based on these ideas it has been proposed that seabirds with a restricted dietary range and with no chances to effect prey switching, will suffer reproductive failures during periods of reduced food availability. Depending on how severe and long is the period of reduced food, seabirds may suffer high mortality (Pierotti \& Annett 1990). On the other hand, seabirds with a broad dietary range and able to switch prey, may display no changes in reproduction and survival, or may even improve their reproductive rate during periods of food shortage of 
their usual food (Stewart et al. 1984).

To explore these ideas we analyzed information available in 10 studies on the effects of the 1982-83 El Niño on seabird populations in four areas of the South Pacific Ocean (Table 1). At Kiritimati Island for a total of 18 species, 17 suffered reproductive failures ranging from $40 \%$ (Lesser Frigatebird) to $100 \%$ (Audubon's Shearwater, Brown Booby, Brown Noddy and Sooty Tern). At French Frigate Shoals there is information on two species that suffered reduction from 10 to $20 \%$ on their chick body sizes. The Galapagos Archipelago showed the most diverse array of effects: Among 22 species, four suffered reductions in both their abundances and reproductive activities, five solely in their abundances, eight in their reproductive activities, three did not show any alteration, one increased in abundance (White-throated Storm Petrel), and one in reproductive activities (Lava Gull). In the case of Peru, among eight species, six experienced reductions in their abundance (ranging from 50 to $90 \%$ ) and two displayed no changes at all (Flightless Cormorant and Inca Tern).

We characterized the diet of 41 seabird species (Table 2). At Kiritimati Island all the species were piscivorous but due to the inclusion of squid in their diet, two different dietary groups (Fig. 1a) were recognized: piscivorous and fish+squid consumers. In these islands the averaged effect of El Niño over the species in this feeding group (Table 1) was a general reduction of $-82 \% \pm 6.26$, this value being $-78 \pm 17.0 \%$ for the piscivorous group and $-85 \pm 4.9$ $\%$ for the fish+squid eaters. Most of the birds in the Galapagos Archipelago consumed fishes, crustaceans and squid, but due to the inclusion of sea lion wastes and fishery wastes, two main dietary groups were recognized in this archipelago (Fig. 1b). The averaged El Niño effect over the species in this feeding group (data in Table 1) on the Galapagos birds was $-27 \pm 6.2 \%$, which corresponded to $-31 \pm 6.7 \%$ for fish, crustacean and squid eaters, and to $-2 \pm$ $3.3 \%$ for consumers of fish+crustacean+squid+sea lion waste +fishery waste. In Peru, two dietary groups (Fig. 1c) were identified: fish consumers (7 species) and fish+squid consumers (Inca terns). The averaged effect of El Niño (Table 1) on these birds was $-57 \pm 14.1 \%$, corresponding to $-80 \pm 12.7 \%$ for fish consumers and $+5 \pm 0.0 \%$ for Inca terns. Our results show that in general there is an inverse relationship between El Niño events and the breadth
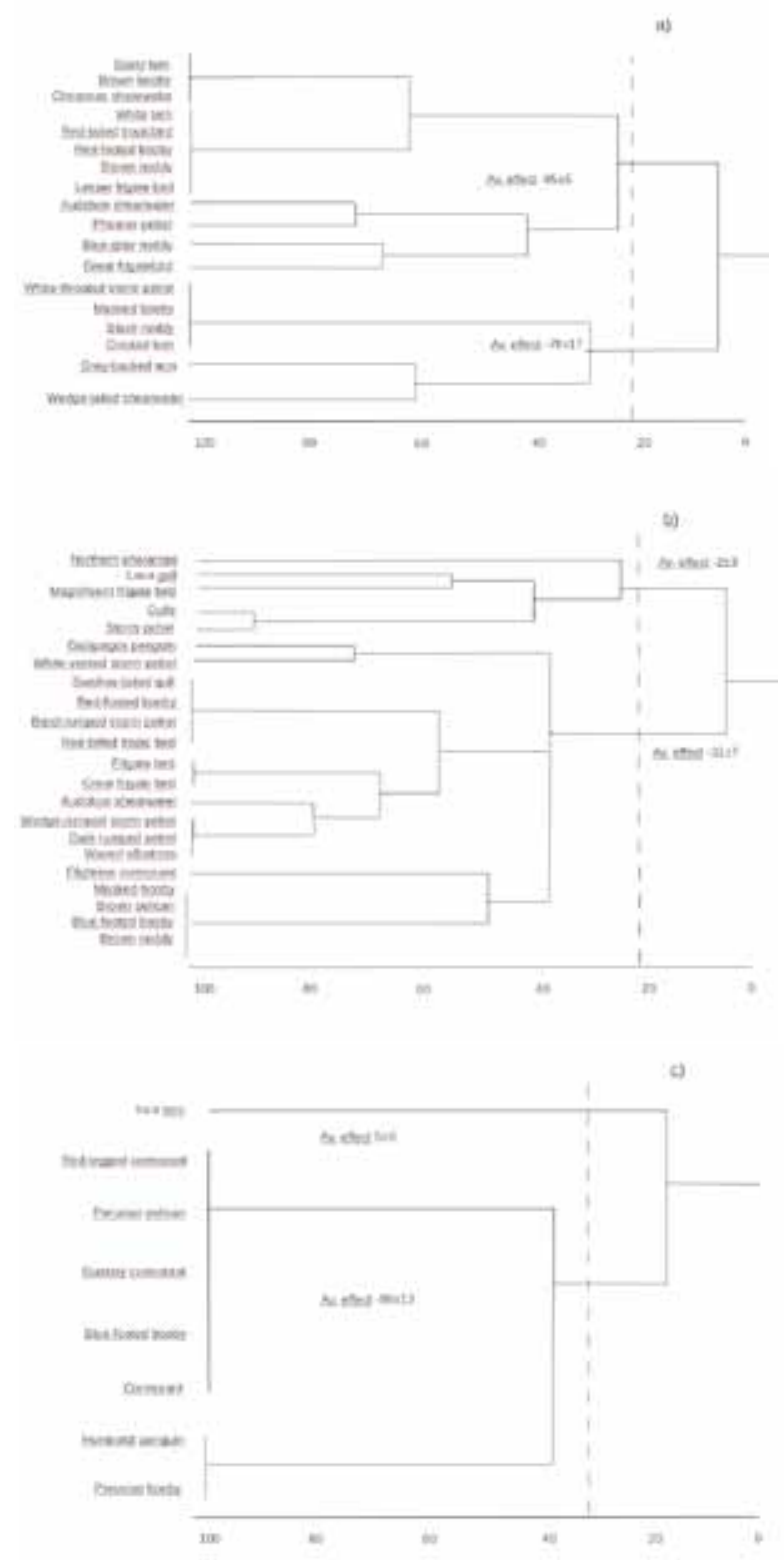

Fig. 1. Percent dietary similarities on seabird species of three southeastern Pacific Ocean regions: (a) Kiritimati Island, (b) Galapagos Archipelago, (c) Peru. Dashed line defines the limit of similarity for the dietary groups $(\propto<0.05)$. The averaged effect of El Niño 1982-83 for each recognized dietary group is shown (based on data in tables 1 and 2).

of seabird diets. Seabirds with a narrow dietary breadth (e.g., those eating fish and fish larvae) were the most severely affected by El Niño 1982-83, while species eating more than four different prey items 
(species from the Galapagos Archipelago) were less affected. In addition, it appears that the inclusion of crustaceans, and specially fishery wastes or carrion (sea lion wastes), in the diet alleviated the shortage of food. Seabirds with the ability to switch and use these food types (i.e., Inca tern in Peru) were basically not affected by El Niño.

\section{Waterbirds}

The distribution and area of wetlands are highly variable and depend on climate conditions, especially rainfall. Any change in these variables has the potential to impact strongly on birds dependent on such habitats. Analyses of El Niño effects on waterbird populations are scarce. In the southeastern Pacific, no reports were issued on this group of birds during the 1982-83 event, but three studies (Vilina \& Cofré 2000,Vilina et al. 2002, Schlatter et al. 2002) were developed in Chilean wetlands during El Niño 1997-98.

Vilina \& Cofré (2000) analyzed the presence, seasonal abundance, and habitat associations of four grebe species: White-tufted Grebe (Rollandia rolland), Silver Grebe (Podiceps occipitalis), Great Grebe (Podiceps major) and Pied-billed Grebe (Podilymbus podiceps), in a central Chilean wetland. They found a positive correlation between spring abundance of all these species and total rainfall the previous year. Rain fell chiefly during the winter and spring of the El Niño year (1997); grebe populations increased during the summer (beginning of 1998), and peaked during the spring of 1998. Further, the Silver Grebe bred in the wetland studied only during the $\mathrm{El} \mathrm{Niño}$ and post-El Niño years.

Vilina et al. (2002) analyzed the relationship between the 1997-98 El Niño event, rainfall, and changes in abundance, breeding and local distribution of an endemic bird of southern South America, the Black-necked Swan (Cygnus melancoryphus), in a central Chilean wetland. During and after the El Niño event, Black-necked Swan increased in abundance, breeding success, and time of presence (from seasonal to year-around) in the wetland studied. Based on Vilina et al.'s (2002) observations it seems logical to predict that during the alternate phase of El Niño (that is, La Niña), which brings drought conditions, a reduction in Black-necked Swan abundance and possibly increased migration to southerly wetlands may occur.

In the context of waterbird migration, Schlatter et al. (2002) developed the idea that Black-necked Swan populations in a wetland of southern Chile fluctuated within years due to seasonal rainfall patterns and between years due to El Niño events. They hypothesized that because of migration from northern wetlands (with unstable water levels), populations in the south peaked during dry years associated with $\mathrm{La}$ Niña. Their results showed that numbers of swans more than doubled during the La Niña period of 1996 to mid-1997. These periods coincided with a regional drought that forced northerly wetland swans to move nomadically toward the south, where Rio Cruces is a water stable wetland and a likely population source for Black-necked Swans for all of Chile.

Thus, waterbirds seem to benefit from precipitation that accompanies El Niño, which enlarges the water surface of marshes, coastal lagoons, and other waterbodies. Increased wetland habitat then affords more opportunities for building adequate nests and obtaining sufficient food.

\section{Landbirds}

Landbirds are affected by El Niño in two contrasting ways: Negatively, because when El Niño arrives, excessive precipitation may result in nesting failure and increased chick mortality due to nest flooding, thus lowering reproductive success. The subsequent drought years that follow El Niño (usually the reverse phase of La Niña) further decimate bird populations because of the depletion of food resources, which may trigger reduced allocation of energy to breeding. These negative effects have been reported in the Galapagos Archipelago (Gibbs \& Grant 1987, Grant \& Grant 1987, 1993, Hall et al. 1988), Snares Islands of New Zealand (Miskelly 1990), Hawaii (Lindsey et al. 1997), and continental Argentina (Masello \& Quillfeldt 2003). On the other hand, El Niño-driven precipitation fires up primary productivity (aboveground plant biomass and seed crop), which in turn fuels arthropod and mammal increases in semiarid regions of South America, thus positively affecting bird populations.

\section{Granivorous birds}

There is information on the response of granivorous birds to seed availability for three sites, presented here in chronological sequence. On Daphne Island, Ecuador, seed abundance (mass in the soil) increased strongly with the El Niño year of 1983, and remained high in 1984 (Fig. 2). Finch abundance 


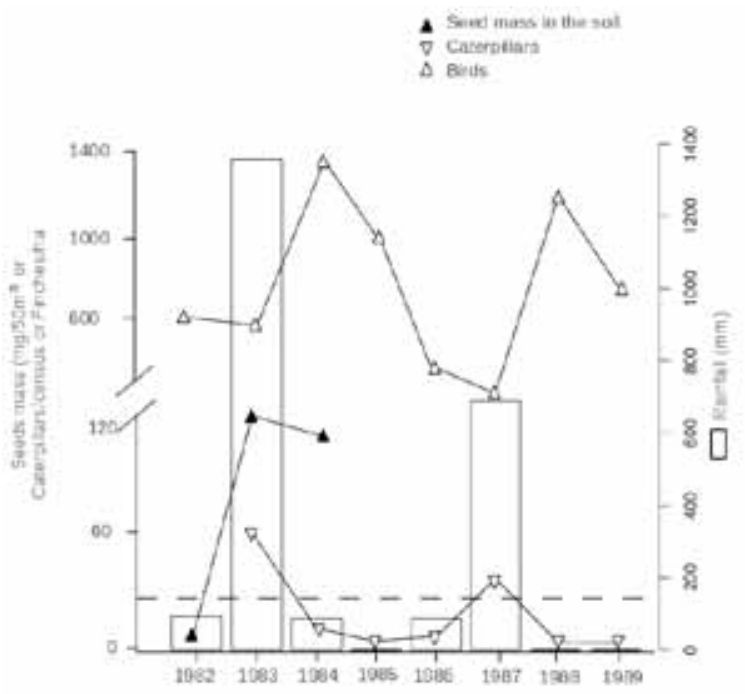

Fig. 2. Yearly course of finch abundance (1982-1989), total seed biomass (1982-1984) and caterpillar abundance (19831989), together with rainfall (1982-1989) in Daphne Island, Galapagos Archipelago. Mean annual rainfall is shown as dashed line. El Niño events occurred in 1982-83 and 1987.

peaked one year after the rainfall and seed peak of 1983, subsequently declined, and again peaked with a one-year lag after the high-rainfall year brought by El Niño 1987. Although this time no record was kept of seed abundance, the similarity in pattern

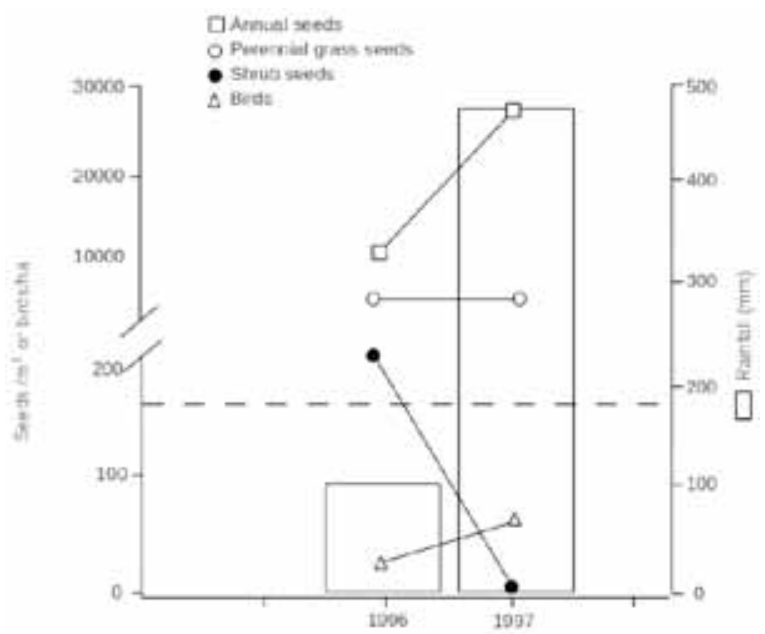

Fig. 3. Yearly course of bird abundance, seed abundance of different types, together with rainfall (1996-1997),

in Auco, northern Chile. Mean annual rainfall is shown as dashed line. An El Niño event occurred in 1997.

seems beyond coincidence. It is interesting to note that caterpillars also were in high abundance during El Niño years of 1983 and 1987, and that finches

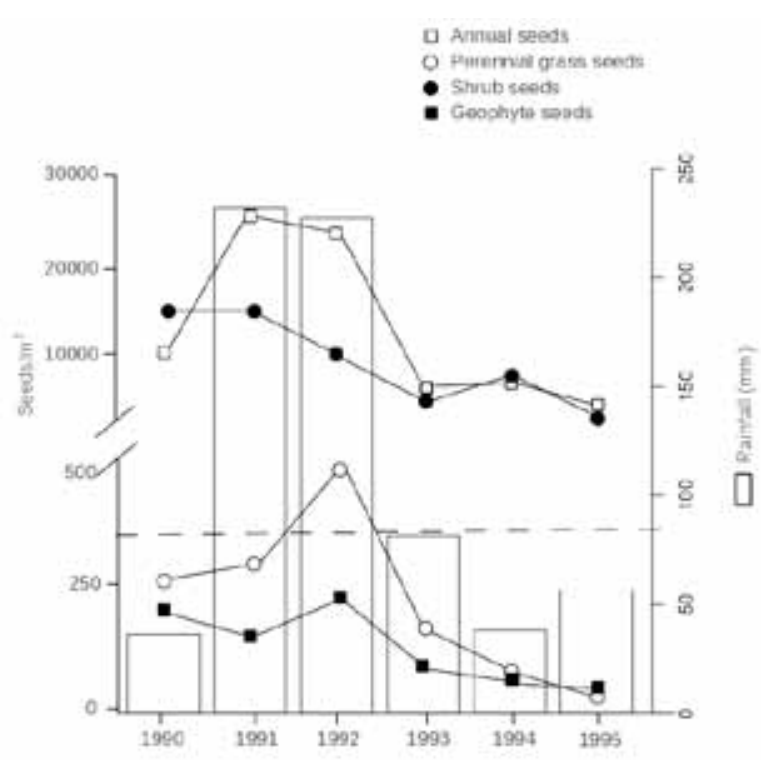

Fig. 4. Yearly course of seed abundance of different types, together with rainfall (1990-1995), in Fray Jorge, northern Chile. Mean annual rainfall is shown as dashed line. An El Niño event occurred in 1991-92

use these prey to feed their nestlings.

In Auco, semiarid Chile, the increased rainfall brought by El Niño 1997-98 resulted in an immediate increase in annual herb seeds, in a lack of response in perennial herb seeds, and in a decrease in shrub seeds. Granivorous birds increased in abundance from 26 to $58 /$ ha by $123 \%$ (Fig. 3). A similar phenomenon was described in Fray Jorge, semiarid Chile, where the increased rainfall brought by El Niño 1991-92 resulted in an immediate increase in annual herb seeds, a slower one in perennial herb seeds, a 1-yr delayed increase in geophyte seeds, and a decrease in shrub seeds (Fig. 4). Unfortunately, no tally was kept of granivorous bird abundance.

In Ñacuñan, Monte desert of Argentina, El Niño of 1997 brought increased precipitation (but there may be other important climatic influences at play, see Compagnucci et al. 2002). Higher rainfall did not elicit a response from perennial herbs or forbs, but there was a marked increase in seed germination and seedling survivorship (Fig. 5). Nevertheless, bird abundance remained flat (López de Casenave 2001) ${ }^{4}$.

The response of granivorous birds to peaks in seed output reported above is suggestive. Both in Daphne Island and in Auco there was a positive response. In Nacuñan there was no increase in seed crop to which the birds could respond. The 


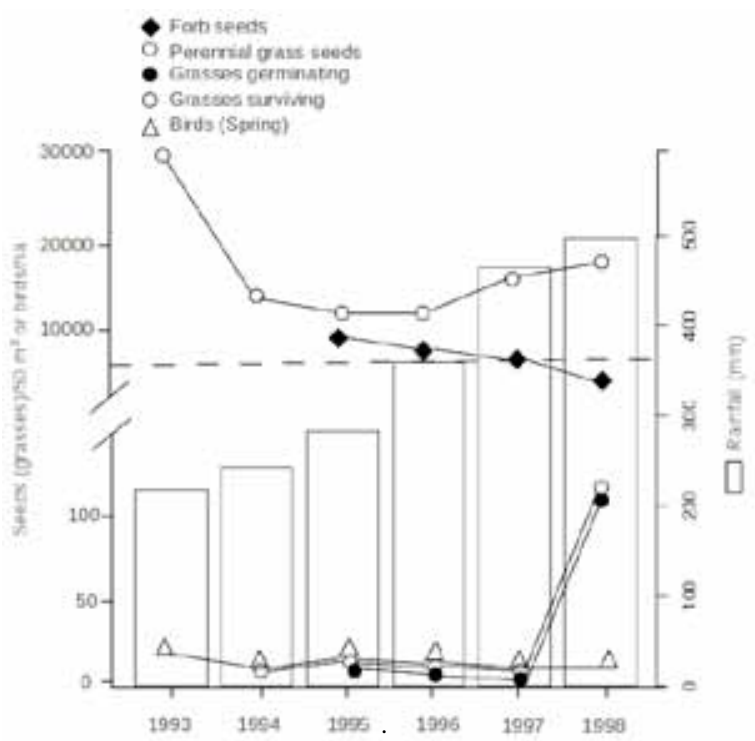

Fig. 5. Yearly course of bird abundance, seed abundance of different types, seed germination and survival, together with rainfall (1993-1997), in Ñacuñan, western Argentina. Mean annual rainfall is shown as dashed line. An El Niño event occurred in 1997.

best database, that from Fray Jorge, did not simultaneously record bird abundance and thus did not contribute to make a better case for the coupling between seeds and birds.

\section{Insectivorous birds}

Information on the response of birds to arthropod availability exists for only two sites, presented chronologically here. On Daphne Island, Ecuador, caterpillar abundance was high during the El Niño year of 1983, and decreased thereafter until El Niño 1987, which resulted in another caterpillar peak (Fig. 2). Unfortunately, the tally kept for bird abundance considered only finches, and not true insectivores.

In Auco, semiarid Chile, insect and insectivorous bird populations decreased after the El Niño of 1991-92 until the augmented rainfall brought by El Niño 1997-98 resulted in a simultaneous increase in arthropod and bird abundance (Fig. 6). Unfortunately, the monitoring data covering the following three years disappeared, and thus the response of insects and birds to El Niño 2002 was obscured by the lack of preceding background. Nevertheless, a plot of insectivorous bird abundance against arthropod abundance yielded a diminishing return (Fig. 7). The functional response of insectivorous birds was steep at the start, but tended to saturate quickly, reaching an asymptote. Again, the response of insectivorous birds to peaks in insects reported above is suggestive, but marred by lack of consistent monitoring.

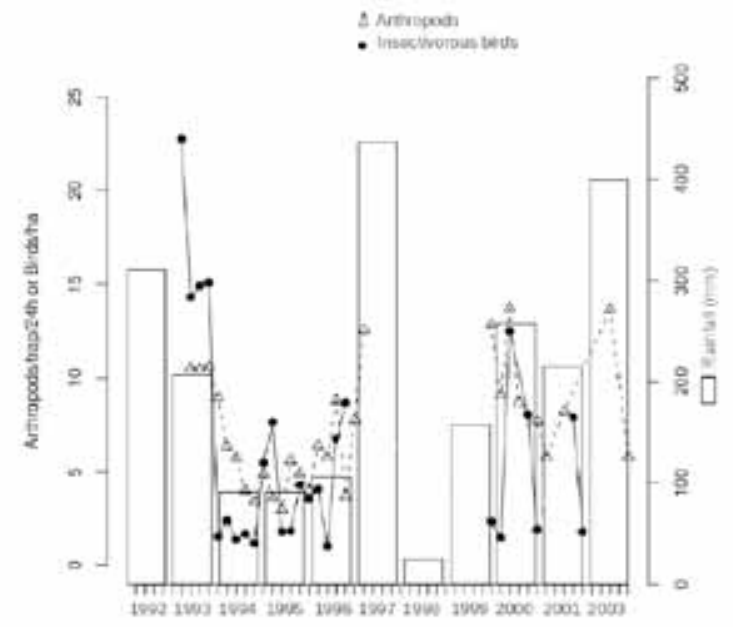

Fig. 6. Seasonal course of the abundance of insectivorous birds and arthropod prey, together with yearly rainfall (19922002) in Auco, northern Chile. No animal data are available 1998-2000. During winter and spring 2002 arthropods could not be sampled. Yearly rainfall corresponds to precipitation accumulated from autumn (March) to summer the following year (February). Mean annual rainfall is shown as dashed line. El Niño events occurred in 1991-92, 1997, 2002.

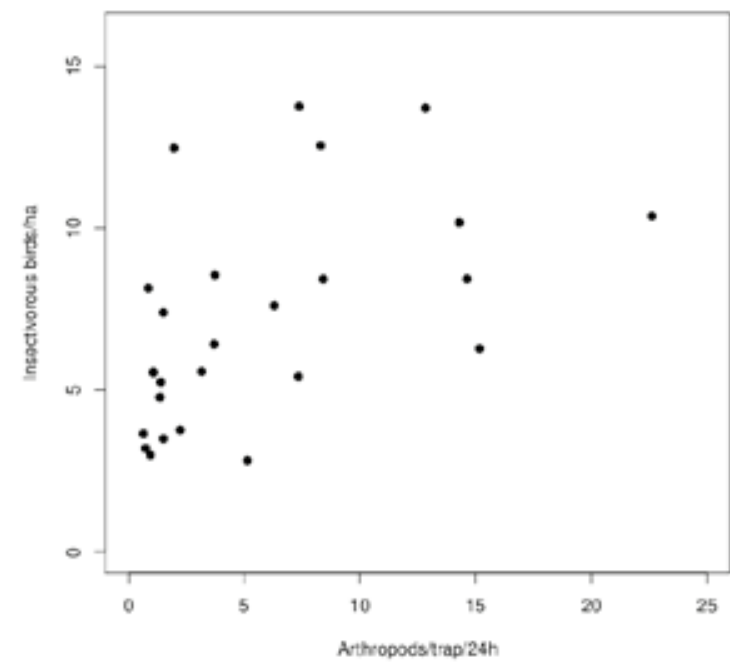

Fig. 7. Relationship between insectivorous bird and arthropod prey abundance in Auco, northern Chile. Each datapoint corresponds to a calendar season $(n=26)$. The regression line corresponds to the best fit by Vernier Graphical Analysis 3.1. 


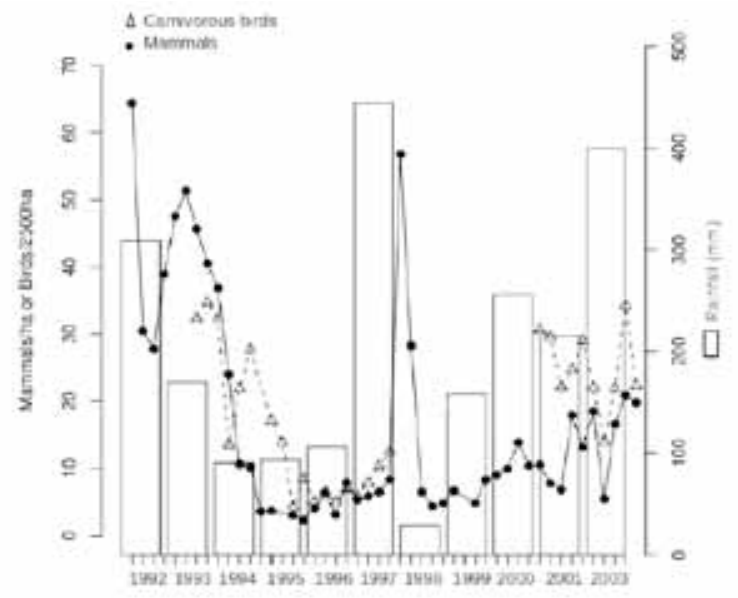

Fig. 8. Seasonal course of the abundance of carnivorous birds and mammal prey, together with yearly rainfall (1992-

2002) in Auco, northern Chile. Bird sampling started in winter 1993. No bird data are available 1998-2000.

Yearly rainfall corresponds to precipitation accumulated from autumn (March) to summer the following year

(February). Mean annual rainfall is shown as dashed line. El Niño events occurred in 1991-92, 1997, 2002.

\section{Carnivorous birds}

Only one site exists with simultaneous monitoring of carnivorous bird populations (raptors in the orders Falconiformes and Strigiformes) and of their

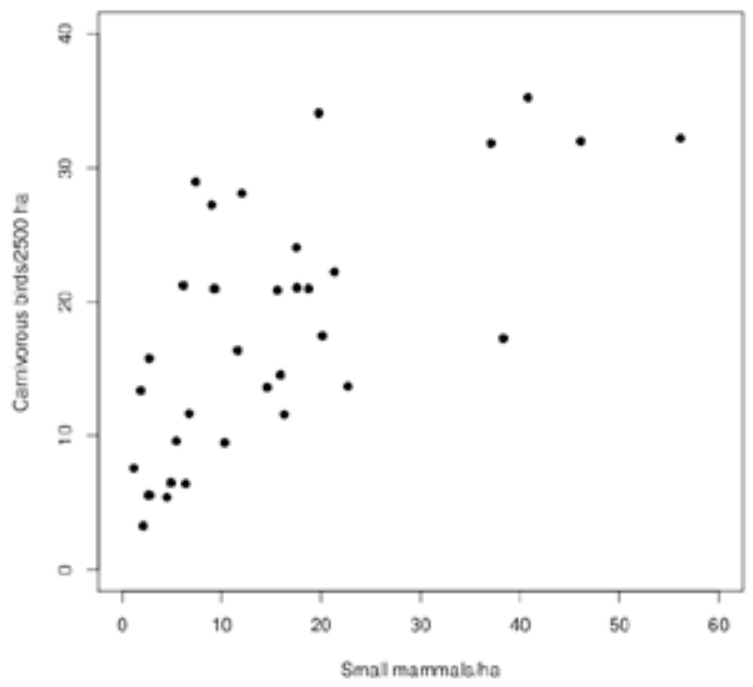

Fig. 9. Relationship between carnivorous bird and mammal prey abundance in Auco, northern Chile. Each datapoint corresponds to a calendar season ( $n=28$ ). The regression line corresponds to the best fit by Vernier Graphical Analysis 3.1. main prey, small mammals. In Auco, semiarid Chile, mammal and carnivorous bird populations were declining after El Niño of 1991-92 until augmented rainfall brought by El Niño 1997-98 resulted in a simultaneous increase of mammal and bird abundances (Fig. 8). As mentioned above, raptor census data covering the following three years disappeared, but still the response of mammals and birds to $\mathrm{El}$ Niño 2002 is suggestive. Indeed, a plot of carnivorous bird abundance against mammal abundance yielded a curve of diminishing returns. As with the insectivores, the functional response of carnivorous birds was steep initially, but tended to saturate quickly, clearly reaching an asymptote (Fig. 9). In this case, there is no ambiguity in the response of carnivorous birds to their prey resources, although the missing three years of data dent an otherwise good picture.

\section{DISCUSSION}

In this section we discuss four major points that arise from the findings reported here: (a) Food shortage may be an important key factor for bird populations, but its effects depend on diet breadth, prey switching, and life history parameters of the birds involved. (b) Predictable (seasonal) patterns of productivity may determine distribution and abundance of resident birds, but variations imposed by unpredictable occurrences of El Niño and La Niña may determine the presence and abundance of migratory birds in areas affected by these anomalies. (c) The dichotomy El Niño versus La Niña phases or versus 'normal' years is artificial and leads to an impoverished view of the dynamics of bird populations and communities. (d) Long-term monitoring is needed to understand the connection between climate and birds.

\section{Effects of El Niño depend on bird diet}

It is widely recognized that El Niño produces important changes in seabird populations (Arntz \& Fahrbach 1991). However, not all events have been analyzed in similar depth. The 1982-83 El Niño was the best documented, while those of 1986-87 (e.g. Anderson 1989) and 1991-92 (e.g. Lindsay et al. 1997) were practically ignored. During 1997-98 there was a renewed interest on the phenomenon, but most studies were directed at specific changes in particular species (e.g. Culik et al. 2000, Jahncke \& Goya 2000, Simeone et al. 2002), lacking the general perspective used in the analyses of the 1982-83 
event (e.g. Arntz \& Fahrbach 1996). In spite of this, and based chiefly on information reported for the 1982-83 and 1997-98 events, the primary effects of El Niño on seabirds are related to availability of anchovy and sardine, which may be related to primary production in the marine food web and with the effects of rain and runoffs on seabird nesting grounds (Schreiber 2002). No specific mechanisms have been proposed to explain the interaction between oceanographic and atmospheric anomalies with seabird population changes. Our results show that food shortage may be an important underlying cause but that its net effects depend on seabird diet breadth and prey switching. In terms of reproduction, it has been proposed that the rapid changes in primary productivity occurring during and after El Niño events could be an important selective factor for breeding biology and life history patterns of seabirds (Luna-Jorquera et al. 2003). Common patterns among species with rapid recoveries after $\mathrm{El}$ Niño are: large clutch sizes, high body growth rates, and early reproductive ages. Luna-Jorquera et al. (2003) showed that, at least for the Humboldt Current system, which is frequently affected by El Niño, the seabird assemblages are dominated by species with the stated characteristics. It could further be predicted that land, and seabirds showing rapid responses to abrupt increases in primary productivity (El Niño in terrestrial habitats and La Niña in marine habitats), should display similar life history attributes (diet breadth, prey switching, large clutches, early maturity).

\section{El Niño imposes unpredictability to bird assemblages}

The structure of bird assemblages (species composition and relative abundances) may be determined by basal levels of primary productivity, but also by the seasonal and ENSO fluctuations of that variable. Hurlbert \& Haskell (2003) analysed the structure of terrestrial bird assemblages in relation to fluctuations of primary productivity across the United States. They showed that basal levels of primary productivity determine resident species richness, while the range of predictable variation (seasonality) of this variable determines migrant species richness. The approach of Hurlbert \& Haskell (2003) could be used in the search of general mechanisms for ENSO effects on both terrestrial and marine bird assemblages. It could be that superimposed on predictable (seasonal) changes of productivity, the range of variation imposed by unpredictable but rather frequent occurrences of El Niño and La Niña determine geographic distribution and population abundance of the birds living in areas affected by these anomalies.

\section{El Niño and La Niña are extremes of a wide range of variability}

The occurrence (and magnitude) of El Niño is declared after some pre-defined threshold is reached, according to atmospheric and/or oceanographic indices such as sea surface temperature (SST) and southern oscillation index (SOI, Boersma 1998). Nevertheless, physical fluctuations (anomalies) are continuously occurring at different time scales. These anomalies are usually treated as departures from normality, where 'normal' (ocean/atmosphere) conditions represent either climatic means or nonEl Niño/La Niña conditions. Thus, normality is not treated as a real phenomenon (a state of some system) but as the absence of extreme conditions. However, El Niño/La Niña thresholds encompass a wide range of real physical fluctuations that may have effects on bird assemblage attributes. In addition, there appears to be a weak correlation between the magnitude of El Niño/La Niña events as measured by physical indices, and the magnitude of recorded biological effects. Therefore, physical and biological dynamics do not have a direct coupling, and thus environmental signals may be filtered or processed by terrestrial and marine communities in such ways that they may resist some El Niño/La Niña events regardless of their magnitude. Both in marine and terrestrial systems, the phenomenology of community changes during El Niño/La Niña events is portrayed as an alternation between bottom-up to top-down control (e.g. Cury et al. 2000, Meserve et al. 2003). Nevertheless, while productivity is a central variable during those events, bottom-up effects may not preclude biological feedbacks at higher trophic levels. Conversely, decreased productivity may not necessarily lead to a strict control by predators or herbivores.

\section{The need for long-term time series}

It seems obvious that without good baseline data ornithologists are doomed to be surprised by the arrival of El Niño every few years. Even when ornithologists and ecologists are at hand to take advantage of an incoming El Niño, lack of preexisting data, and of monitoring afterwards, makes it difficult 
to understand responses of birds to the successive $\mathrm{El}$ Niño, La Niña, and "normal" years. Indeed, according to Jaksic (2001), during the last century there were 12 El Niño years and 12 La Niña years, thus leaving about 76 'normal' years in between. Thus, by heavily concentrating attention on only $12 \%$ of the time span (El Niño), and of neglecting possibly another $12 \%$ (La Niña), ornithologists are essentially ignoring what happens during $76 \%$ of the time. This situation may be remedied only as long as data are logged on a regular or continuous basis, that is, as long-term time series (Crawford \& Jahncke 1999). The recipe prescribed by Schreiber \& Schreiber (1988) to understand El Niño effects on birds still stands: '...carry out long-term studies that will shed further light on the interactions between global atmospheric cycles, oceanographic phenomena, and avian populations.'

TABLE 1. Effects of El Niño 1982-83 on seabird species in four localities of the southeastern Pacific Ocean Increases in abundance are coded by $+\%$ and decreases by $-\%$. Increases in reproduction (nesting densities) are denoted by $+\%$ and decreases by -\%. Decreases in chick survival are denoted by -Csurv and decreases in chick size by -Csize. Lack of changes are denoted by (=). Sources are listed in the footnote

\begin{tabular}{|c|c|c|c|c|}
\hline Localities and species & Species & Abund. & Reprod. & Source \\
\hline a) Kiritimati Island & & & & \\
\hline Audubon's Shearwater & Puffinus Iherminieri & & -100 & 7 \\
\hline Black Noddy & Anous minutus & & -100 & 7 \\
\hline Blue-gray Noddy & Procelsterna cerulea & & -95 & 7 \\
\hline Brown Booby & Sula leucogaster & & -100 & 7 \\
\hline Brown Noddy & Anous stolidus & & -100 & 7 \\
\hline Christmas Shearwater & Puffinus nativitatis & & -80 & 7 \\
\hline Crested Tern & Thalasseus bergii & $=$ & $=$ & 7 \\
\hline Gray-backed Tern & Sterna lunata & & -99 & 7 \\
\hline Great Frigatebird & Fregata minor & & -90 & 7 \\
\hline Lesser Frigatebird & Fregata ariel & & -40 & 7 \\
\hline Masked Booby & Sula dactylatra & & -98 & 7 \\
\hline Phoenix Petrel & Pterodroma alba & & -80 & 7 \\
\hline Red-footed Booby & Sula sula & & -70 & 7 \\
\hline Red-tailed Tropicbird & Phaethon rubricauda & & -90 & 7 \\
\hline Sooty Tern & Sterna fuscata & & -100 & 7 \\
\hline Wedge-tailed Shearwater & Puffinus pacificus & & -75 & 7 \\
\hline White Tern & Gygis alba & & -85 & 7 \\
\hline $\begin{array}{l}\text { White-throated Storm Petrel } \\
\text { b) French Frigate Shoals }\end{array}$ & Nesofregetta albigularis & & -100 & 7 \\
\hline Black Noddy & Anous tenuirostris & & -20, -Csize & 1 \\
\hline $\begin{array}{l}\text { Red-footed Booby } \\
\text { c) Galapagos Archipelago }\end{array}$ & Sula sula & & $-10,-C s i z e$ & 1 \\
\hline Audubon's Shearwater & Puffinus lherminieri & -5 & -100 & 5,9 \\
\hline Band-rumped Storm-petrel & Oceanodrama castro & $=$ & $=$ & 5 \\
\hline Blue-footed Booby & Sula nebouxii & -5 & -100 & 5,9 \\
\hline Brown Noddy & Anous stolidus & -5 & & 5 \\
\hline
\end{tabular}




\begin{tabular}{|c|c|c|c|c|}
\hline Brown Pelican & Pelecanus occidentalis & $=$ & -100 & 5,9 \\
\hline Dark-rumped Petrel & Pterodroma phaeopygia & +5 & $-42,-$ Csize & $1,5,9$ \\
\hline Flightless Cormorant & Nannopterum harrisi & & -50 & 9,10 \\
\hline Frigatebird & Fregata sp. & -5 & & 5 \\
\hline Galapagos Penguin & Spheniscus mendiculus & -5 & -77 & 5,9 \\
\hline Great Frigatebird & Fregata minor & & $-52,-$ Csurv & 9 \\
\hline Gulls & Larus sp. & $=$ & $=$ & 5 \\
\hline Lava Gull & Larus fuliginosus & & +5 & 9 \\
\hline Magnificent Frigatebird & Fregata magnificent & $=$ & $-5,-$ Csurv & 9 \\
\hline Masked Booby & Sula dactylatra & $=$ & -100 & 5,9 \\
\hline Northern Phalarope & Lobipes lobatus & -5 & & 5 \\
\hline Red-billed Tropicbird & Phaethon aethereus & -5 & $=$ & 5,9 \\
\hline Red-footed Booby & Sula sula & & -100 & 9 \\
\hline Storm-Petrel & Oceanites sp. & +5 & & 5 \\
\hline Swallow-tailed Gull & Creatus furcatus & -5 & 100 & 5,9 \\
\hline Waved Albatross & Diomedea irrorata & $=$ & -60 & 5,9 \\
\hline Wedge-rumped Storm-petrel & Oceanites tethys & -5 & -100 & 5,9 \\
\hline $\begin{array}{l}\text { White-vented Storm-petrel } \\
\text { d) Peru }\end{array}$ & Oceanites gracilis & $=$ & $=$ & 5 \\
\hline Blue-footed Booby & Sula nebouxii & -50 & & 1,3 \\
\hline Cormorant & Phalacrocorax sp. & $=$ & $=$ & 2 \\
\hline Guanay Cormorant & Phlacrocorax bougainvilli & -80 & & $6,8,4$ \\
\hline Humboldt Penguin & Spheniscus humboldti & -90 & & 6 \\
\hline Inca Tern & Larosterna inca & $=$ & $=$ & 2,6 \\
\hline Peruvian Booby & Sula variegata & -80 & & $1,6,3,8,4$ \\
\hline Peruvian Pelican & Pelecanus thagus & -80 & $=$ & $2,6,8,4$ \\
\hline Red-legged Cormorant & Phalacrocorax gaimardi & -85 & & 6 \\
\hline
\end{tabular}

Sources: 1 = Ainley et al. (1988), 2 = Arntz (1985), 3 = Arntz \& Fahrbach (1996), 4 = Duffy (1983a), 5 = Duffy \& Merlen (1986), 6 = Duffy et al. (1988), 7 = Schreiber \& Schreiber (1984), $8=$ Tovar \& Cabrera (1985), 9 = Valle et al. (1987), 10 = Valle \& Coulter (1987).

TABLE 2. Dietary composition and similarity (clusters, see text for explanation) of seabird species in four localities of the southeastern Pacific Ocean affected by El Niño 1982-83

Main prey: 1 = Zooplankton, 2 = Fish larvae, 3 = Fishes, $4=$ Eel, $5=$ Octopi, $6=$ Crustaceans, $7=$ Squid, 8 = Sandworms, 9 = Seabirds, 10 = Turtles, 11 = Iguanas, 12 = Sealion wastes, $13=$ Fishery wastes

\begin{tabular}{|c|c|c|c|c|c|c|c|c|c|c|c|c|c|}
\hline Seabirds and prey & 1 & 2 & 3 & 4 & 5 & 6 & 7 & 8 & 9 & 10 & 11 & 12 & 13 \\
\hline \multicolumn{14}{|l|}{ a) Kiritimati Island } \\
\hline Audobon shearwater & & $\mathrm{X}$ & $X$ & & & $\mathrm{X}$ & $\mathrm{X}$ & & & & & & \\
\hline Blue-gray noddy & & & $\mathrm{X}$ & & & $\mathrm{X}$ & $\mathrm{X}$ & & & & & & \\
\hline Brown booby & & $\mathrm{X}$ & $\mathrm{X}$ & & & & $\mathrm{X}$ & & & & & & \\
\hline Brown noddy & & & $\mathrm{X}$ & & & & $\mathrm{X}$ & & & & & & \\
\hline Christmas shearwater & & $\mathrm{X}$ & $\mathrm{X}$ & & & & $\mathrm{X}$ & & & & & & \\
\hline Great frigate bird & & & $\mathrm{X}$ & & & $X$ & $\mathrm{X}$ & & & & & $\mathrm{X}$ & \\
\hline
\end{tabular}


Lesser frigate bird

$\begin{array}{rlll} & X & & X \\ X & X & X & X \\ X & & & X \\ & & X \\ X & & & X \\ X & & & X \\ X & & & X \\ & X & \end{array}$

Crested tern

Gray-backed tern

Masked booby

X X

$\mathrm{X}$

Wedge-tailed shearwater

White-throated storm petrel

b) French frigate shoals

Black noddy

Red-footed booby

$\mathrm{X}$

$\mathrm{X}$

c) Galapagos Archipelago

Gulls

Lava gull

Magnificent frigate bird

Northern phalarope

Oceanites sp. Storm-petrel

Audobon shearwater

Band-rumped storm-petrel

Blue-footed booby

Brown noddy

Brown pelican

Dark-rumped petrel

Flightless cormorant

Frigatebird

Galapagos penguin

Great frigate bird

X X

$\mathrm{X}$

$\begin{array}{ll}X & X \\ X & \\ X & \\ X & \end{array}$

Masked booby

Red-billed tropicbird

Red-footed booby

Swallow-tailed gull

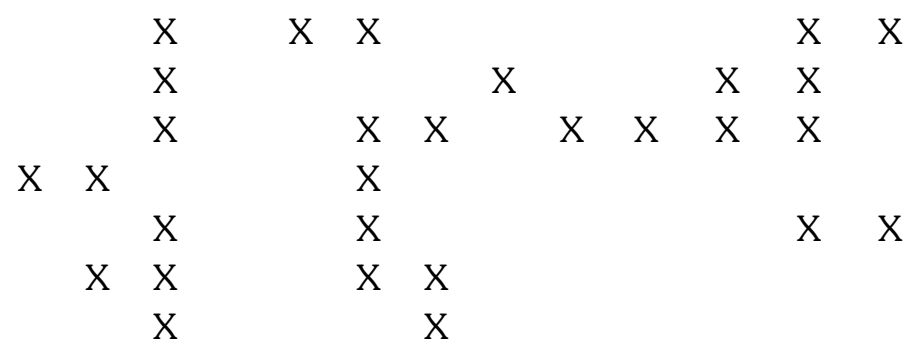

Waved albatross

$\mathrm{X}$

$\mathrm{X}$

$\mathrm{X}$

$\begin{array}{lll}X & X & X\end{array}$

$\mathrm{X} X \mathrm{X}$

$X \quad X \quad X$

$\mathrm{X}$

$\mathrm{X} \quad \mathrm{X}$

X $\quad X \quad X$

$\mathrm{X}$

$\mathrm{X}$

$X \quad X$

$\mathrm{X} \quad \mathrm{X}$

$\mathrm{X} \quad \mathrm{X}$

$\begin{array}{lll}X & X & X\end{array}$

Wedge-rumped storm-petrel

$\begin{array}{lll}X & X & X\end{array}$

White-vented storm-petrel

d) Peru

Inca tern

Blue-footed booby

$\mathrm{X}$

$\mathrm{X}$

$X \quad X$


Cormorants X

Guanay cormorant X

Humboldt penguin $\quad \mathrm{X}$

Peruvian Booby $\quad \mathrm{X}$

Peruvian Pelican X

Red-legged Cormorant X
$\mathrm{X}$

$\mathrm{X}$

\section{ACKNOWLEDGMENTS}

This research was funded by grant FONDAPFONDECYT 1501-0001 to the Center for Advanced Studies in Ecology \& Biodiversity. We thank Javier Figueroa and Sergio Silva for drafting some of the graphs, and Luis Marone and Javier López de Casenave for information from Argentina. David C. Duffy kindly commented on a previous draft of this paper, as well as David Ainley, Lisa T. Balance, and two anonymous reviewers.

\section{LITERATURE CITED}

Ainley, D. G. 1976. The occurrence of seabirds in the coastal region of California. Western Birds 7:33-68.

Ainley, D. G. \& R. J. Boekelheide (Eds) 1990. Seabirds of the Farallon Islands: Ecology, Dynamics, and Structure of an Upwelling System Community. Stanford University Press, Palo Alto. California, 450 pp.

Ainley, D. G. \& G. J. Divoky 2001. Seabirds: Effects of climate change. In: Encyclopedia of Ocean Sciences (Eds J. Steele, S. Thorpe \& K. Turekian) pp. 2669-2677. (Academic Press, London).

Ainley, D. G. \& G. J. Hyrenbach 2010. Top-down and bottom-up factors affecting seabird population trends in the California current system (1985-2006). Progress in Oceanography 84:242-254.

Ainley, D. G., H. R. Carter, D. W. Anderson, K. T. Briggs, M. C. Coulter, F. Cruz, J. B. Cruz, C. A.Valle, S. I. Fefer, S. A. Hatch, E. A. Schreiber, R. W. Schreiber \& N. G. Smith 1988. Effects of the 1982-83 El Niño-Southern Oscillation on Pacific Ocean bird populations. Proceedings of the International Ornithological Congress 19:1747-1758.
Ainley, D. G., W. J. Sydeman, R. H. Parrish \& W. R. Lenarz 1993. Oceanic factors influencing distribution of young rockfish (Sebastes) in central California: a predator's perspective. California Cooperative of Oceanographic Fisheries Investigations, Report 34:133-139.

Ainley, D. G., W. J. Sydeman \& J. Norton 1995. Upper-trophic level predators indicate interannual negative and positive anomalies in the California Current food web. Marine Ecology Progress Series 118:69-79.

Anderson, D. J. 1989. Differential responses of boobies and other seabirds in the Galapagos north Pacific Ocean to the 1986-87 El NiñoSouthern Oscillation event. Marine Ecology Progress Series 52:209-216.

Anderson, D. W. \& I. T. Anderson 1976. Distribution and status of Brown Pelicans in the California Current. American Birds 30:3-12.

Arntz, W. E. 1985. Biological ambivalence of El Niño 1982-83. In: El fenómeno El Niño y su impacto en la fauna marina (Eds W. E. Arntz, A. Landa \& J. Tarazona) pp. 1-35. Boletín Extraordinario del Instituto del Mar del Perú, Callao, Perú.

Arntz, W. E. \& E. Fahrbach 1996. El Niño, experimento de la naturaleza. Fondo de Cultura Económica, D. F., México.

Ashmole, N. P. \& M. J. Ashmole 1967. Comparative feeding ecology of sea birds of a tropical oceanic island. Yale University, Peabody Museum of Natural History, Bulletin 24.

Baird, P. H. 1990. Influence of abiotic factors and prey distribution on diet and reproductive success of three seabird species in Alaska. Ornis Scandinavica 21:224-235.

Boersma, P. D. 1978. Breeding patterns of Galapagos penguins as an indicator of oceanographic 
conditions. Science 200:1489-1493.

Boersma, P. D. 1998. Population trends of the Galapagos Penguin, impacts of El Niño and La Niña. Condor 100:245-253.

Castro, I. \& A. Phillips 1996. A guide to the birds of the Galapagos Islands. Christopher Helm, A. \& C. Black, London, UK.

Chávez, F. P., J. Ryan, S. E. Lluch-Cota \& M. Ñiquen 2003. From anchovies to sardines and back: Multidecadal change in the Pacific Ocean. 299:217-221.

Clarke, K. R. 1993. Non-parametric multivariate analyses of changes in community structure. Australian Journal of Ecology 18:117-143.

Compagnucci, R. H., E. A. Agosta \& W. M. Vargas 2002. Climatic change and quasi-oscillations in central-west Argentina summer precipitation, main features and coherent behaviour with southern African region. Climate Dynamics 18:421-435.

Crawford, R. J. M. \& J. Jahncke 1999. Comparison of trends in abundance of guano-producing seabirds in Peru and southern Africa. South African Journal of Marine Science 21:145156.

Cruz, J. B. \& F. Cruz 1990. Effect of El-Niño-Southern Oscillation conditions on nestling growth rate in the dark-rumped petrel. Condor 92:160-165.

Culik, B., J. Hennicke \& T. Martin 2000. Humboldt penguins outmaneuvering El Niño. Journal of Experimental Biology 203:2311-2322.

Cury, P., A. Bakun, R. J. M. Crawford, A. JarreTeichmann, R. A. Quiñones, L. J. Shannon \& H. M. Verheye 2000. Small pelagics in upwelling systems: Patterns of interaction and structural changes in "wasp-waist" ecosystems. ICES Journal of Marine Science, Symposium Edition, 57(3):603-618.

Duffy, D. C. 1983a. Environmental uncertainty and commercial fishing, effects on Peruvian guano birds. Biological Conservation 26:227-238.

Duffy, D. C. 1983b. The foraging ecology of Peruvian seabirds. Auk 100:800-810.

Duffy, D. C. 1990. Seabirds and the 1982-1984 El Niño-Southern Oscillation. In: Global ecological consequences of the 1982-83 El Niño event (Ed P. W. Glynn) pp. 395-415. Elsevier Oceanographic Series, Elsevier, Amsterdam.

Duffy, D.C., C. Hays \& M.A. Plenge 1984 The conservation status of Peruvian seabirds. In Status and Conservation of the World's Seabirds (Eds J. P. Croxall, P. G. H. Evans \& R. W. Schreiber) pp. 245-259. Technical Publications $\mathrm{N}^{\circ} 2$, International Council for Bird Preservation, Cambridge.

Duffy, D. C. \& G. Merlen 1986. Seabird densities and aggregations during the $1983 \mathrm{El}$ Niño in the Galapagos Islands. Wilson Bulletin 98:588-591.

Duffy, D. C., W. E. Arntz, H. T. Serpa, P. D. Boersma \& R. L. Norton 1988. A comparison of the effects of El Niño and the Southern Oscillation on birds in Peru and the Atlantic Ocean. Proceedings of the International Ornithological Congress 19:1740-1746.

England, M. C. 2000. A review of bird responses to El Niño-Southern Oscillation conditions in the Neotropics. Cotinga 13:83-88.

Gibbs, H. L. \& P. R. Grant 1987. Ecological consequences of an exceptionally strong $\mathrm{El}$ Niño event on Darwin's finches. Ecology 68:1735-1746.

Goodman, D. 1974. A cost ceiling on reproductive effort. American Naturalist 108:247-268.

Grant, P. R. \& B. R. Grant 1987. The extraordinary El Niño event of 1982-83, effects on Darwin's finches on Isla Genovesa Galapagos. Oikos 49:55-66.

Grant, P. R., B. R. Grant, L. F. Keller \& K. Petren 2000. Effects of El Niño events on Darwin's finch productivity. Ecology 81:2442-2457.

Graybill, M. R. \& J. Hodder 1985. Effects of the 1982-83 El Niño on the reproduction of six species of seabirds in Oregon. In: El Niño North: Niño Effects in the Eastern Subarctic Pacific Ocean (Eds W. S. Wooster \& D. L. Fluharty) pp. 205-210. University of Washington Sea Grant Programme, Seattle, Washington. Gutiérrez, J. R. \& P. L. Meserve 2003. El Niño effects on soil seed bank dynamics in north-central Chile. Oecologia 134:511-517.

Gutiérrez, J. R., G. Arancio \& F. M. Jaksic 2000. Variation in vegetation and seed bank in a Chilean semi-arid community affected by ENSO 1997. Journal of Vegetation Science 11: 641-648.

Hall, G. A., H. L. Gibbs, P. R. Grant, L. W. Botsford \& G. S. Butcher 1988. Effects of El NiñoSouthern Oscillation (ENSO) on terrestrial birds. 
Proceedings of the International Ornithological Congress 19:1759-1775.

Harris, M. P. 1979. Population dynamics of the flightless cormorant Nannopterum harrisi. Ibis 121:135-146.

Hays, C. 1986. Effects of the 1982-83 El Niño on Humboldt penguin colonies in Peru. Biological Conservation 36:169-180.

Herdson, D. 1984. Changes in the demersal fish stocks and other marine life in Ecuatorian coastal waters during the 1982-83 El Niño. Tropical Ocean and the Atmosphere Newsletters 28:14-16.

Hurlbert, A. H. \& J. P. Haskell 2003. The effect of energy and seasonality on avian species richness and community composition. American Naturalist 161:83-97.

Jaccard, P. 1901. Distribution de la flore alpine dans le basin de dranses et dan quelques region voisines. Bulletin du la Societe Vaudoise du Science Naturelle 37:241-272.

Jahncke, J. \& E. Goya 2000. Responses of Three Booby Species to El Nino 1997-1998. Waterbirds 23:102-108.

Jaksic, F. M. 2001. Ecological effects of El Niño in terrestrial ecosystems of western South America. Ecography 24:241-250.

Jaksic, F. M. 2004. El Niño effects on avian ecology, lessons learned from the southeastern Pacific. Plenary Lecture at 7th Neotropical Ornithological Congress, Termas de Puyehue, Chile. Ornitología Neotropical (Suppl.) 15:61-72.

Jaksic, F. M. \& I. Lazo 1999. Response of a bird assemblage in semiarid Chile to the 19971998 El Niño. Wilson Bulletin 111:527-535.

Lindsey, G. D., T. K. Pratt, M. H. Reynolds \& J. D. Jacobi 1997. Response of six species of Hawaiian forest birds to a 1991-1992 El Niño drought. Wilson Bulletin 109:339-343.

Ludwig, J. L., C. S. Robbins, K. L. Cousins \& C. L. Summer 2000. A comparison of recruitment among 11 age classes of black-footed albatross, Phoebastria nigripes chicks from Midway Atoll, 1960-79: evidence for El Niño and fisheries impacts. Marine Ornithology 28:135-136.

Luna-Jorquera, G., A. Simenone \& R. Aguilar 2003. Ecofisiología de animales endotermos en un desierto cálido y un mar frío: El caso de las aves marinas de la corriente de Humboldt.
In Fisiología Ecológica y Evolutiva (Ed. F. Bozinovic) pp. 341-368. Ediciones Universidad Católica de Chile, Santiago, Chile.

Marone, L., E. Horno \& R. González del Solar 2000. Post-dispersal fate of seeds in the Monte desert of Argentina, patterns of germination in successive wet and dry years. Journal of Ecology 88:940-949.

Masello, J. F. \& P. Quillfeldt 2003. Body size, body condition and ornamental feathers of Burrowing Parrots, variation between years and sexes assortative mating and influences on breeding success. Emu 103:149-161.

Massey, B. W., D. W. Bradley \& J. L. Atwood 1992. Demography of a California least tern colony including effects of the 1982-1983 El Niño. Condor 94:976-983.

Meserve, P. L., D. A. Kelt, W. B. Milstead \& J. R. Gutiérrez 2003. Thirteen years of shifting top-down and bottom-up control. BioScience 53:633-646.

Miskelly, C. M. 1990. Effects of the 1982-83 El Niño event on two endemic landbirds on the Snares Islands New Zealand. Emu 90:24-27.

Montevecchi, W. A. \& R. A. Myers 1995. Prey harvest of seabirds reflects pelagic fish and squid abundance on multiple spatial and temporal scales. Marine Ecology Progress Series 117: 1-9.

Montevecchi, W. A. \& R. A. Myers 1996. Dietary changes of seabirds indicate shifts in pelagic food webs. Sarsia 80:313-322.

Montevecchi, W. A., V. L. Birt \& D. K. Cairns 1998. Dietary changes of seabirds associated with local fisheries failures. Biological Oceanography 5:153-161.

Murphy, R. C. 1925. The bird islands of Peru. Putman, New York.

Murphy, R. C. 1926. Oceanic and climatic phenomena along the west coast of South America during 1925. Geophysical Review 16:26-54.

Murphy, R. C. 1936. Oceanic birds of South America. McMillan, New York. 2 vol.

Pierotti, R. \& C. A. Annett 1990. Diet and reproductive output in seabirds. BioScience 40:568-574.

Schlatter, R. P., R. A. Navarro \& P. Corti 2002. Effects of El Niño Southern Oscillation on numbers of Black-necked Swans at Rio Cruces Sanctuary Chile. Waterbirds 25:114-122. 
Schreiber, E. A. 1994. El Niño-Southern Oscillation effects on provisioning and growth in red-tailed tropicbirds. Colonial Waterbirds 17:105-119.

Schreiber, E. A. 2002. Climate and weather effects on seabirds. In: Biology of Marine Birds (Eds E. A. Schreiber \& J. Burger) pp. 179-215. CRC Press, Boca Raton, Florida.

Schreiber, E. A. \& R. W. Schreiber 1993. Redtailed Tropicbird (Phaeton rubricauda). In: The Birds of North America No 43 (Eds A. Pole \& F. Gill). Academy of Natural Sciences Philadelphia, American Ornitologists' Union, Washington, DC.

Schreiber, R. W. \& E. A. Schreiber 1984. Central Pacific seabirds and the El Niño-Southern Oscillation, 1982-1983 perspectives. Science 225:713-716.

Schreiber, R. W. \& E. A. Schreiber 1988. Introduction. Proceedings of the International Ornithological Congress 19:1739.

Shealer, D. A. 2002. Foraging behavior and food of seabirds. . In: Biology of Marine Birds (Eds E. A. Schreiber \& J. Burger) pp. 137-179. CRC Press, Boca Raton, Florida.

Simeone, A., B. Araya, M. Bernal, E. Diebold, N. K. Grzybowski, M. Michaels, J. A. Teare, R. S. Wallace \& M. J. Willis 2002. Oceanographic and climatic factors influencing breeding and colony attendance patterns of Humboldt penguins Spheniscus humboldti in central Chile. Marine Ecology Progress Series 227:43-50.

Sneath, P. H. 1957. Some thoughts on bacterial classification. Journal of Genetic Microbiology 17:184-200.

Spear, L. B., L. T. Balance \& D. G. Ainley 2001. Response of seabirds to thermal boundaries in the tropical Pacific, the thermocline versus the Equatorial front. Marine Ecology Progress Series 219:275-289.

Spear, L. B., D. G. Ainley \& W. A. Walker 2007. Foraging dynamics of seabirds in the eastern tropical Pacific Ocean. Studies in Avian Biology 35 (Ed C. D. Marti), 99 pp.

Stewart, B. S., P. K. Yochem \& R. W. Schreiber 1984. Pelagic red crabs as food for gulls, a possible benefit of El Niño. Condor 86:341-342.

Tovar, H. 1983. Fluctuaciones de poblaciones de aves guaneras en el litoral Peruano, 1960-1981. In: Proceedings of the Expert Consultation to Examine Changes in Abundance and Species Composition of Neritic Fish Resources, San José, Costa Rica, April 1983 (Eds G. D. Sharp, and J. Csirke). FAO Fisheries Report 291(3):957-976.

Tovar, H. \& D. Cabrera 1985. Las aves guaneras y el fenómeno 'El Niño'. In: El Niño y su impacto en la fauna marina (Eds W. A. Arntz, A. Landa, \& J. Tarazona) pp. 181-186. (Boletín Extraordinario del Instituto del Mar del Perú, Callao, Special Issue.)

Tovar, H., V. Guillén \& D. Cabrera 1987. Reproduction and population levels of Peruvian guano birds. Journal of Geophysical Research 92 (C):14445-14448.

Valle, C. A. \& M. C. Coulter 1987. Present status of the flightless cormorant Galapagos penguin and greater flamingo populations in the Galapagos Islands Ecuador after the 1982-1983 El Niño. Condor 89:276-281.

Valle, C. A., F. Cruz, J. B. Cruz, G. Merlen \& M. Coulter 1987. The impact of the 1982-1983, El Niño-Southern Oscillation on seabirds in the Galapagos Islands Ecuador. Journal of Geophysical Research 92:14437-14444.

Vilina, Y. A. \& H. L. Cofré 2000. 'El Niño' effects on the abundance and habitat association patterns of four grebe species in Chilean wetlands. Waterbirds 32:95-101.

Vilina, Y. A., H. L. Cofré, C. Silva-García, M. D. García, \& C. Pérez-Friedenthal 2002. Effects of El Niño on abundance and breeding of Black-necked Swans on El Yali Wetland in Chile. Waterbirds 25:123-127.

Wallace, M. P. \& S. A. Temple 1988 Impacts of the 1982-1983 El Niño on population dynamics of Andean Condors in Peru. Biotropica 20:144-150.

Wahl, T. R., D. G. Ainley, A. H. Benedict \& A. R. DeGrange 1989. Associations between seabirds and water masses in the northern Pacific Ocean in summer. Marine Biology 103: 1-11.

Wilkinson, L., G. Blank \& C. Gruber 1996. Desktop data analysis with Systat. Prentice-Hall, Englewood Cliffs, New Jersey. 